\title{
Meta-Analysis Study on Correlation of Workloads and Work Stress Among Nurses in Hospital
}

\author{
Hermansyah $^{1 *} \quad$ Agung Riyadi ${ }^{2}$ \\ ${ }^{1}$ Poltekkes Kemenkes Bengkulu, Nursing Department, \\ J1. Indragiri No. 03 Padang Harapan Bengkulu
}

\begin{abstract}
According to Munandar (2008), one of the factors associated with the occurrence of work stress is workload. Intrinsic sources of work include physical demands and task demands. The workload is one of the demands of the task that becomes a stressor at work. Munandar also stated that excessive or insufficient workload stimulates the stress. Hermansyah and Mardiani (2016) showed that workload is the cause of latent variables of work intrinsic factors. However, there was no significant correlation between the intrinsic factors of work (including workload) and work stress among the nurses in the hospital (t-count $1.33<1.96)$. Prihatini $(2007)$ research showed a significant correlation between workload and work stress in inpatient room at RSUD Sidikalang. The purpose of the study was to determine the correlation between workload and stress among the nurses in the hospital. This study investigated the results of research conducted and published in Indonesia from 2006 to 2017 using two online databases, namely Google Scholar and the University of Indonesia (UI) Library.This study was a literary review with meta-analysis method. Population in this research was all research regarding the correlation between workload and stress among nurses in hospital inpatient room which published in Indonesia from the year 2006 until 2017. Data collection was obtained from an online database, Google Scholar and the University of Indonesia Library. Data analysis involved test to determine Heterogeneity and odds ratio combination (OR) with $95 \%$ confidence interval. The result showed that the percentage of nurse with a heavy workload that had stress was $62.4 \%$, it was greater than $37.6 \%$ of nurses with heavy workload that did not experience work stress, and there was a significant correlation between workload and stress among nurses in hospital (OR 3.3 (95\% CI: 2.3-4.7). It is suggested to Indonesian hospitals to transfer nurses from the heavierworkload ward to the less-workload ward so as to reduce the stress in the heavier-workload ward.
\end{abstract}

Keywords: workload, work stress among nurses, and meta analysis.

DOI: $10.7176 /$ RHSS/9-6-04

Publication date:March $31^{\text {st }} 2019$

\section{Introduction}

Nurses have high psychological distress at work, such as being exposed to several causes of stress ranging from the excessive workload, the pressure to work on tasks, no clarity on rules of staff contract with infectious diseases, patients with critically ill conditions and patients with no vital signs (NIOSH, 2008). Working as a nurse is also prone to stress, according to the Indonesian National Nurses Association (2006, in Muthmainah, 2012) there are $50.9 \%$ of Indonesian nurses in four provinces experiencing stress, with symptoms of frequent dizziness, fatigue, restless because the workload is too high and time-consuming, low salary and inadequate incentives.

According to Soewondo (2010), stress can be seen as a stimulus, a response, or an interaction between individuals and the environment. The concept of stress as a stimulus is described as a stimulus in the environment faced by individuals and considered disturbing. The stress experienced in the workplace is called work stress (Muthmainah, 2012). Spears (2008) defines work stress as a person's reaction to excessive pressure or harmful workplace de-mands. Job stress is also explained as a psychological process that occurs as a consequence of behavior or events in the work environment and creates special psychological, physiological, and individual behavioral consequences (Gibson, 2000).

The impact of work stress can affect the place where individuals work. The impact of stress on the workplace includes obstacles in both management and work operations, disrupting normal work activities, declining levels of work productivity, decreasing income and profits of companies, financial losses experienced by workplaces because of the imbalance between productivity and costs incurred salaries, allowances and other facilities as well as the number of staff who are absent from work, or work that is not completed on time either due to lags or due to many repeated errors. While the impact of stress on individuals is the emergence of various problems related to health, psycho-logical, and social interactions (Rini, 2002).

Simanjorang study (2008) showed that $59.6 \%$ of nurses experienced moderate work stress. Jusnimar study (2012) in Dharmais Cancer Hospital ICU Room investigated that as many as $66.7 \%$ of nurses experienced moderate work stress, and $33.3 \%$ of nurses experienced mild work stress. The results of Ratnaningrum study (2012) found that $33.3 \%$ of nurses in the Intensive Psychiatry Room of Dr. H. Marzoeki Mahdi Hospital Bogor experienced moderate stress. Hermansyah and Mardiani study (2016) in Dr. M. Yunus Hospital Bengkulu 
showed that half $(51.6 \%)$ nurses in the inpatient room showed physical symptoms of mild category work stress, more than half $(51.1 \%)$ showed psychological symptoms of mild category work stress, and more than half (51, $6 \%$ ) nurses showed behavioral symptoms of mild category work stress.

Burnout is one of the most common re-sults of work stress. Specific symptoms in burnout include boredom, depression, pessi-mism, lack of concentration, poor-quality work, dissatisfaction, absence, and pain/illness. The cause of burnout is an excessive workload. Survey on thousands of workers showed that work stress due to excessive workload can be considered as signs of weakness, fragility, and low-secured job. Workers who are unable to control stress will show dissatisfaction performance (National Safety Council, 2004).

According to Munandar (2008), one of the factors associated with the occurrence of work stress is workload. Intrinsic sources of work include physical demands and task demands. The workload is one of the demands of the task that becomes a stressor at work. Munandar also stated that excessive workload or insufficient workload is a stress stimulator.

Muthmainah (2012) pointed out that most nurses who have heavy workload (53.6\%), half of them (53.3\%) experience moderate work stress. While nurses who perceive light workload mostly experience mild work stress. Simanjorang study (2008) showed that task aspect variables (including workload) are the dominant variables that influence the nurse work stress.

Hermansyah and Mardiani (2016) investigated that workload forms latent variables of work intrinsic factors. However, between the intrinsic factors of work (including workload) and the work stress among nurses in the hospital, there is no significant correlation (t count $1.33<1.96)$. Prihatini's study $(2007)$ in the inpatient ward at RSUD Sidikalang showed that there is a significant correlation between workload and work stress.

Inconsistency in some studies encouraged a meta-analysis study that aims to support or reject one of the results of the primary study regarding the correlation between workload and work stress among nurses in the hospital ward. Meta-analysis is a study that analyzes data from primary studies. The results of the primary study analysis are used as a basis for accepting or supporting hypotheses or rejecting/aborting hypotheses that are recommended by several researchers (Sugiyanto, 2004). Meta-analysis is a statistical technique to combine the results of two or more similar studies so that a mixed data can be obtained quantitatively (Anwar, 2005).

The aim of this study was to investigate the correlation between workload and work stress among nurses in Indonesian hospitals.

\section{Method}

This study was a literary review using the meta-analysis method that utilizes data from various primary studies conducted by various parties. The review was carried out on the results of research conducted and published in Indonesia from 2006 to 2017 using online databases namely Google Scholar and the University of Indonesia Library. It was not only done on published journals or articles but also to those that are not published such as theses, dissertations, and research reports. The identification step was done in August until September 2017. A manual search for a conference abstract book was not conducted.

This study included all research articles regarding the correlation between workload and work stress among nurses in Indonesian hospitals with criterion: 1. The population of research is nurses who worked in hospital inpatients ward; 2. Descriptive-Correlation research, case-control design, and crossectional; 3 . The independent variable is workload and the dependent variable is the work stress among nurses; 4. Research articles in Indonesian included in the study.

The data analysis used in this study was heterogeneity test and combined odds ratio (OR). Testing of publication bias was done to avoid biased conclusions in this meta-analysis study. The meta-analysis results were presented in a forest plot, which shows the odds ratio of each study (black box) with its confidence interval (horizontal line). Vertical lines indicated the ratio of odds $=1$ means that there was no difference in effect. The combined odds ratio was described as diamond (diamond).

\section{Result}

\subsection{Identification and Research Article Se-lection}

Identification of research articles was carried out through systematic searches conducted using two online databases, namely Google Scholar and University of Indonesia (UI) Library (http://lib.ui.ac.id/) with keywords of workloads and nurse work stress and it gained 39 research articles. The database obtained from the UI library was 12 research articles while 27 research articles were obtained from Google Scholar.

In detail, the process of identifying and selecting research articles is explained using chart 1. 


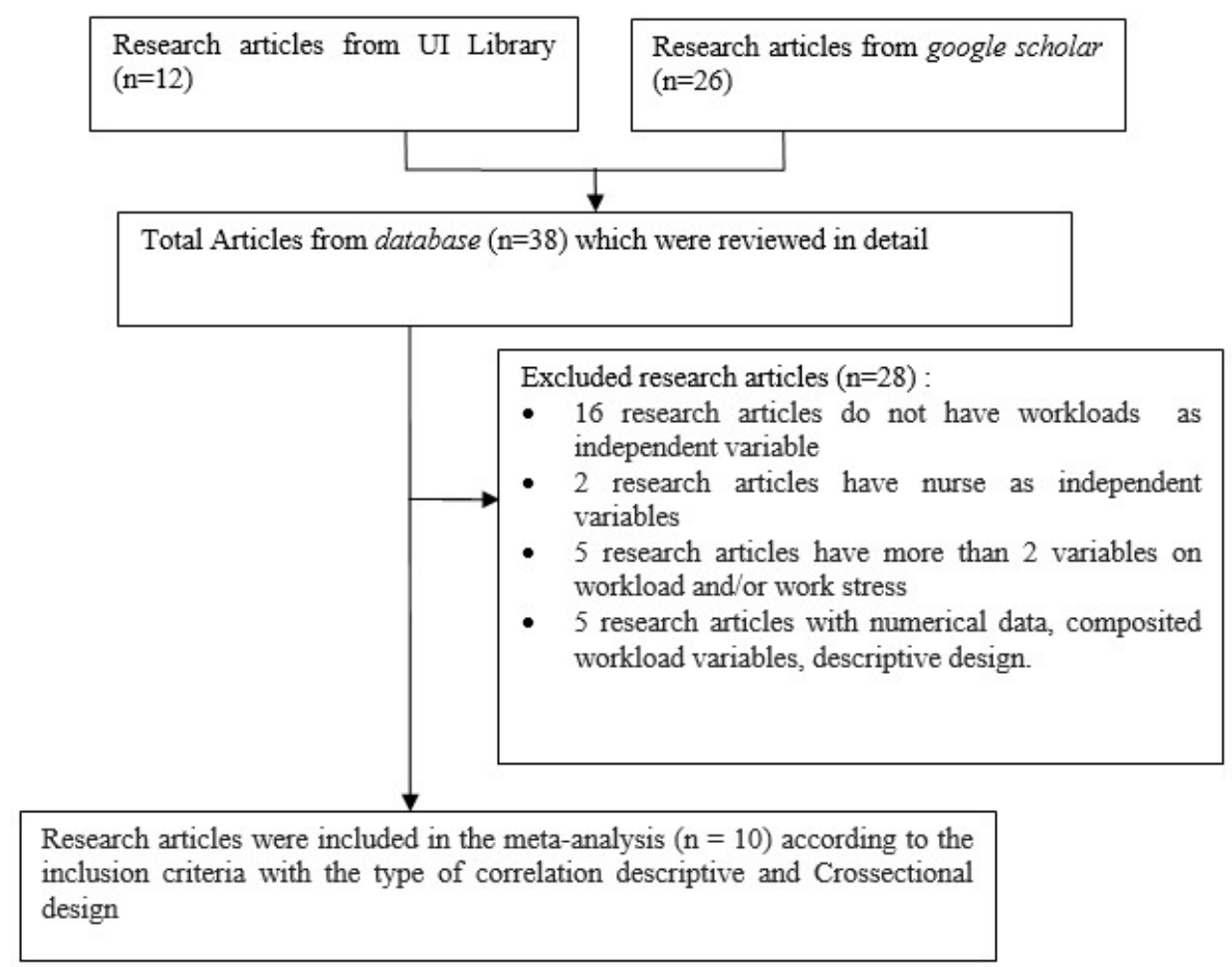

Chart 1. Process of Identification and Selection of Research Articles on Correlation between Workload and Work Stress among Nurses in Indonesian Hospitals

\subsection{Characteristics of Included Research Articles}

The results of the inclusion of re-search articles obtained 10 research articles which could be included in this meta-analysis study which were published research articles in online library databases and national journals found through Google Scholar and UI Library. Research Articles of Pramudya (2008), Suerni (2012), Sari (2013), and Putra (2013) were research articles obtained from UI Library, while 6 other research articles were obtained from Google Scholar.

Research articles included in this meta-analysis study published in Indonesia from 2006 to 2017, were namely from 2008 to 2017. Nine research articles were carried out with a cross-sectional design, and one research article with descriptive correlation. Most research article samples were found in Sari's research article (2013), while the least research sample was found in the Harahap research article (2016).

Furthermore, from 10 research articles that met the inclusion criteria set, only in 2 articles, workload became the main variable, which was in Wagiu (2017) and Haryanti (2013). Eight other research articles raised other variables related to nursing work stress. Included research articles can be seen in table 1 .

\subsection{Characteristics of Excluded Research Articles}

The result of systematic search carried out using two online databases found 28 research articles related to work stress so that they could be included in meta-analysis studies. However, after the identification and selection process, there were 16 research articles on nurse work stress with independent variable but not workload, 2 research articles on nurse work stress as independent variables and not dependent variables, 5 research with more than two categories workload or work stress variables and 5 research articles with numerical data, composited workload variables, descriptive design.

\subsection{Heterogeneity Test Results}

Heterogeneity is a variation. In the heterogeneity test, the role of variation among studies (I2) is calculated on total variation. Variations among studies are variations between studies ( $y)$ divided by total variations $(\mathrm{x}+\mathrm{y}) \mathrm{x}$ $100 \%$. Determination of the role of variation between studies was tested with heterogeneity. If the p-value in the he-terogeneity test is $>0.05$, the null hypothesis fails to be rejected, so it can be concluded that variations between studies do not contribute to the total variation. In other words, among homogeneous studies. To see heterogeneity, it can be done by looking at the $\mathrm{I} 2$ value or p-value in the heteroge-neity test. The conclusion of both is generally the same, homogen or homogeneous (Dahlan, 2012). The results of the heterogeneity test will determine the analysis model to calculate the combined effect. If among homogeneous studies ( $p$-value in 
heterogeneity test $>0.05$ or small I2), the model used is the fixed effect model (FEM). Meanwhile, among heterogeneous studies ( $\mathrm{p}$-value in heterogeneity test $<0.05$ or I2 is large), the model used is the Random effect model (REM) (Dahlan, 2012).

Table 1.Characteristics of Inclusive Research Article in the Meta-Analysis of the Correlation between Workload and Work Stress among Nurses in Indonesian Hospitals

\begin{tabular}{|c|l|c|c|c|c|}
\hline No. & $\begin{array}{c}\text { Researcher and } \\
\text { Year }\end{array}$ & Location & Design & $\begin{array}{c}\text { Sample } \\
\text { Total }\end{array}$ & Significance \\
\hline 1. & Wagiu, 2017 & Rumah Sakit Hermana Lembean & Cross Sectional. & 44 & Yes \\
\hline 2. & Haryanti, 2013 & $\begin{array}{c}\text { Emergency room at RSUD } \\
\text { Kabupaten Semarang }\end{array}$ & $\begin{array}{c}\text { Descriptive } \\
\text { Correlation. }\end{array}$ & 29 & Yes \\
\hline 3. & Septian, 2014 & $\begin{array}{c}\text { Rumaknt Jiwa Daerah Dr. Amini } \\
\text { Dondoutomo Semarang }\end{array}$ & Cross Sectional. & 56 & No \\
\hline 4. & Saragih, 2008 & $\begin{array}{c}\text { Inpatient room Rumah Sakit Umum } \\
\text { Daerah Porsea }\end{array}$ & Cross Sectional. & 70 & Yes \\
\hline 5. & Pramudya, 2008 & Rumah Sakit Ketergantungan Obat & Cross Sectional. & 72 & No \\
\hline 6. & Suerni, 2012 & ICU at West Java General Hospital & Cross Sectional. & 76 & Yes \\
\hline 7. & Sari, 2013 & $\begin{array}{c}\text { Rumah Sakit Jiwa DR. Soeharto } \\
\text { Heerdjan }\end{array}$ & Cross Sectional. & 100 & No \\
\hline 8. & Putra, 2013 & $\begin{array}{c}\text { Rumah Sakit Tugu Ibu } \\
\text { Cimanggis }\end{array}$ & Cross Sectional. & 99 & Yes \\
\hline 9. & Harahap, 2016 & ICU at RSUD Rantauprapat & Cross Sectional. & 17 & No \\
\hline 10. & Anggreny, 2013 & $\begin{array}{c}\text { Rumah Sakit Islam Siti Khadijah } \\
\text { Palembang }\end{array}$ & Cross Sectional. & 73 & Yes \\
\hline
\end{tabular}

\subsection{Correlation between Workload and Stress among Nurses in the Hospital}

The strength of the correlation was indicated by the value of Odds Ratio (OR) in 10 selected studies with the type of descriptive correlation design of a cross-sectional study that shows the value of the relationship through OR, where the smallest OR value was 0.5 and the largest OR was 28.5. There were two studies that have OR values $<2$, namely Pramudya (2008), OR $=1.56$ (95\% CI: 0.5-5.2), and Harahap (2016) OR $=0.50$ (95\% CI: $0.1-3.5)$. Other studies showed the value of $\mathrm{OR} \geq 2$ which indicates that workload is one of the risk factors for the occurrence of work stress on nurses.

Table 2. Heterogeneity Test of Correlation between Workload and Work Stress among Nurses in Indonesian Hospitals.

\begin{tabular}{cccccc}
\hline Q-Value & df & $\mathbf{T}^{2}$-Value & $\mathbf{I}^{2}$-Value & Z/DF & P-Value \\
\hline 15.2 & 9 & 0.2354 & 0.401 & 6.02 & 0.09 \\
\hline
\end{tabular}

Table 3. Research Distribution of Correlation between Workload and Work Stress among Nurses in Indonesian Hospitals After Meta Analysis Analysis was conducted

\begin{tabular}{|l|c|c|c|c|c|c|}
\hline \multicolumn{1}{|c|}{$\begin{array}{c}\text { Researcher and } \\
\text { Year }\end{array}$} & $\mathbf{N}$ & $\mathbf{O R}$ & $\begin{array}{c}\text { Lower } \\
\text { Specification } \\
\text { Limit }\end{array}$ & $\begin{array}{c}\text { Upper } \\
\text { Specificatio } \\
\text { n Limit }\end{array}$ & $\begin{array}{c}\boldsymbol{p} \\
\text { value }\end{array}$ & $\begin{array}{c}\text { Relative } \\
\text { Weight }\end{array}$ \\
\hline Wagiu, 2017 & 44 & 28.500 & 5.585 & 145.440 & 0.000 & 4.9 \\
\hline Haryanti, 2013 & 29 & 5.750 & 0.296 & 111.879 & 0.248 & 1.5 \\
\hline Septian, 2014 & 56 & 3.889 & 1.010 & 14.971 & 0.048 & 7.2 \\
\hline Saragih, 2008 & 70 & 4.386 & 1.475 & 13.045 & 0.008 & 11.0 \\
\hline Pramudya, 2008 & 72 & 1.563 & 0.473 & 5.158 & 0.464 & 9.1 \\
\hline Suerni, 2012 & 76 & 6.429 & 2.316 & 17.848 & 0.000 & 12.5 \\
\hline Sari, 2013 & 100 & 2.263 & 1.013 & 5.052 & 0.046 & 20.2 \\
\hline Putra, 2013 & 99 & 2.611 & 1.100 & 6.197 & 0.030 & 17.4 \\
\hline Harahap, 2016 & 17 & 0.500 & 0.070 & 3.550 & 0.488 & 3.4 \\
\hline Anggreny, 2013 & 73 & 3.454 & 1.259 & 9.478 & 0.016 & 12.8 \\
\hline Fixed Effect Models & 636 & 3.289 & 2.292 & 4.719 & 0.000 & \\
\hline
\end{tabular}

Based on table 3. it can be seen that there were 10 studies on the correlation between workload and work stress among nurses in Indonesian hospitals from 2008-2017 involving 636 subjects, of which 274 subjects experienced heavy workload and 362 subjects did not experience heavy workload. Of the 636 subjects, there were 171 subjects with heavy workload who experienced work stress and 103 subjects with heavy workload who 
did not experience work stress. Furthermore, there are 120 subjects with less-heavy workload who experience work stress and 242 subjects with less-heavy workload who did not experience work stress.

\begin{tabular}{|c|c|c|c|c|c|c|c|}
\hline \multirow[t]{2}{*}{ Studyname } & \multirow[b]{2}{*}{$\begin{array}{l}\text { Odds } \\
\text { ratio }\end{array}$} & \multicolumn{3}{|c|}{ Statistics for each study } & \multicolumn{3}{|c|}{ Exposed/ Total } \\
\hline & & $\begin{array}{l}\text { Lower } \\
\text { limit }\end{array}$ & $\begin{array}{c}\text { Upper } \\
\text { limit }\end{array}$ & Z-Value & p-Value & Cases & Controls \\
\hline Vagiu, 2017 & 28.500 & 5.585 & 145.440 & 4.028 & 0.000 & $19 / 22$ & $4 / 22$ \\
\hline tanyanti, 2013 & 5.750 & 0.296 & 111.879 & 1.155 & 0.248 & $23 / 24$ & $4 / 5$ \\
\hline eptian, 2014 & 3.889 & 1.010 & 14.971 & 1.975 & 0.048 & $6 / 12$ & $9 / 44$ \\
\hline , 2008 & 4.386 & 1.475 & 13.045 & 2.658 & 0.008 & $20 / 39$ & $6 / 31$ \\
\hline Pramudya, 2008 & 1.563 & 0.473 & 5.158 & 0.732 & 0.464 & $10 / 15$ & $32 / 57$ \\
\hline 12 & 6.429 & 2.316 & 17.848 & 3.572 & 0.000 & $24 / 32$ & $14 / 44$ \\
\hline Sari, 2013 & 2.263 & 1.013 & 5.052 & 1.992 & 0.046 & $28 / 46$ & $22 / 54$ \\
\hline Putra, 2013 & 2.611 & 1.100 & 6.197 & 2.176 & 0.030 & $17 / 35$ & $17 / 64$ \\
\hline Harahap, 2016 & 0.500 & 0.070 & 3.550 & -0.693 & 0.488 & $3 / 9$ & $4 / 8$ \\
\hline \multirow[t]{2}{*}{ Anggreny, 2013} & 3.454 & 1.259 & 9.478 & 2.407 & 0.016 & $21 / 40$ & $8 / 33$ \\
\hline & 3.289 & 2.292 & 4.719 & 6.464 & 0.000 & & \\
\hline
\end{tabular}

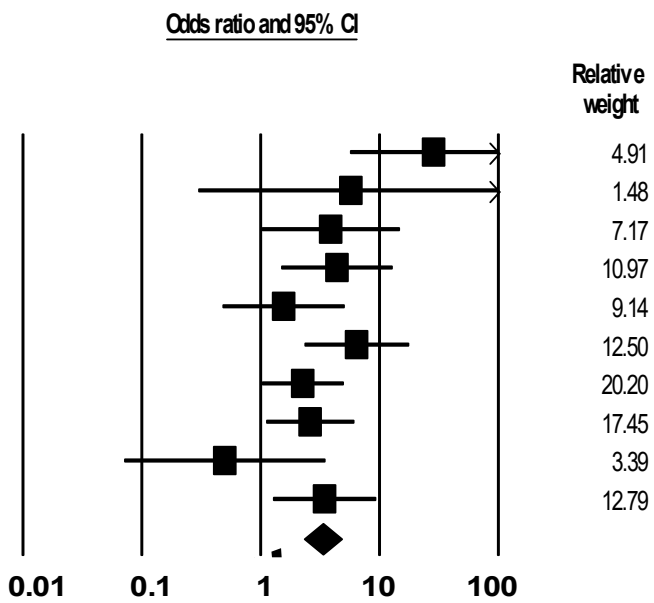

Chart 2. Meta-Analysis of the Correlation between Workload and Work Stress among Nurses in Indonesian Hospitals

Based on the calculation of the combined odds ratio on the fixed effect model, there was a significant correlation between workload and work stress among nurses in Indonesian hospitals $(p=0.000)$. The percentage of nurses with heavy workloads who experienced work stress was $62.4 \%$ greater than the percentage of nurses with heavy workloads who did not experience work stress which was $37.6 \%$. OR value of 3.3 showed that nurses with heavy workload had a 3.3 times riskier to experiencing work stress compared to those with less-heavy workloads (95\% CI: $2.3-4.7)$.

\subsection{Publication Bias}

Publication Bias can be tested through distribution on Funnel Plots. The Funnel Plot displayed the Log Odds Ratio and Standard Error from the Log Odds Ratio for each study. Funnel Plot research on correlation between workload and work stress among nurses in Indonesian hospitals can be seen in chart 3.

\section{Funnel Plot of Standard Error by Log odds ratio}

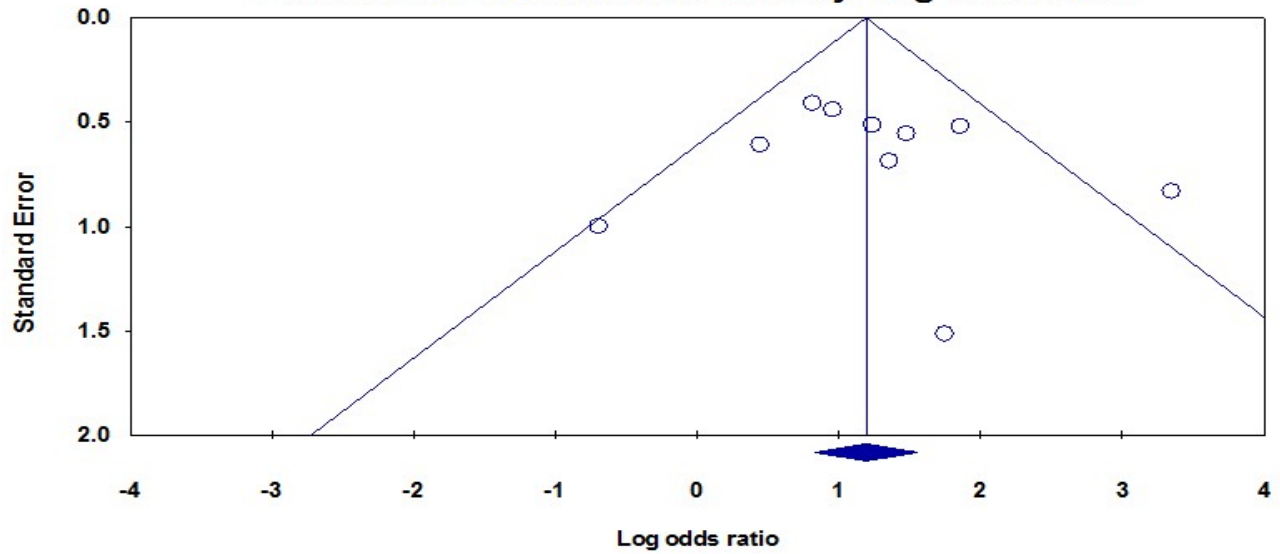

Chart 3. Research Funnel Plot of Correlation between Workload and Work Stress among Nurses in Indonesian Hospitals

Based on the Plot from Chart 3. it can be seen that the research is spread evenly on the left and right vertical lines, so there is no bias due to the balanced research (Sutrisna et al., 2009). Statistical test results with Begg's test showed $\mathrm{p}=0.59151>0.05$ (two sides) which means there is no statistical publication bias.

\section{Discussion}

Ten studies were analyzed in a meta-analysis of the study of the correlation between workload and work stress among nurses in Indonesian hospitals from 2016-2017. This meta-analysis involved 636 subjects, of which 274 subjects had a heavy workload and 362 subjects who did not have a heavy workload. Of the 636 subjects, there were 171 subjects with heavy workloads experienced work stress and 103 subjects with heavy workloads did not experience work stress. Furthermore, there are 120 subjects with less heavy workload experienced work stress and 242 subjects with less heavy workload did not experience work stress. The heterogeneity test results showed 
I 2 value $=41 \%$ and p-value $0.09>0.05$ so it could be concluded that the study of the correlation between workload and work stress among nurses in Indonesian hospitals was homogeneous. Based on the results of the heterogeneity test, the model used was the fixed effect model (FEM).

There were eight clinically significant studies, namely Wagui (2007), Haryanti (2013), Septian (2014), Saragih (2008), Suerni (2012), Sari (2013), Putra (2013), and Anggreny (2013) research. While the two studies were not clinically significant, namely Pramudya (2008) and Harahap (2016).

Wagui (2017) showed that nurses in inpatient ward with heavy workload are 28.5 times more risky of experiencing work stress compared to those with less-heavy workloads. This research was in line with the research of Haryanti (2013) which showed nurses in inpatient ward with heavy workload are 5.75 times greater to experience work stress compared to those with a less-heavy workload.

In Septian's study (2014) it was found that nurses in inpatient ward with heavy workload are 38.9 times prone to have work stress compared to those with less-heavy workloads. The same result was also found in Saragih (2008) where nurses in inpatient ward are 4.39 times more risky to experience work stress compared to those with the less-heavy workload.

Suerni's (2012) showed that nurses in inpatient ward with heavy workload are 6.43 times greater to have work stress compared to those with the less-heavy workload. This finding was in line with Sari's research (2013) which showed that nurses in inpatient ward with heavy workload are 2.27 times greater to have work stress compared to those with the less-heavy workload.

Putra in his study (2013) showed that nurses in inpatient ward with heavy workload are 2.61 times to experience work stress times more risky of experiencing work stress compared to those with the less-heavy workload. This research was in line with the research of Anggreny (2013) which showed that nurses in inpatient ward with heavy workload are 3.45 times more risky of experiencing work stress compared to those with the less-heavy workload t.

The results showed a significant correlation between workload and work stress among nurses in Indonesian hospitals. The percentage of nurses with heavy workloads who experienced work stress was $62.4 \%$ greater than the percentage of nurses $37.6 \%$ with heavy workloads who did not experience work stress. OR 3.3 showed that nurses with heavy workloads are 3.3 times riskier to have work stress compared to those who do not have heavy workloads.

The workload is an effort to detail the components and target volume of work in units of time and units of specific results (Hasibuan, 2002). Whereas Marquish (2000) defines nurse workload is all activities carried out by a nurse while on duty in a nursing service unit. A workload is usually interpreted as patient days which refers to the number of procedures, examinations, visits to patients, injections and so on.

Gillies (1996) states that to estimate the workload of nurses in a unit, managers must collect data regarding the number of patients entering the unit every day / month / year, condition or level of patient dependence in the unit, average days of care patient, type of nursing action needed by the patient, frequency of each nursing action needed by the patient, average time needed to provide nursing treatment.

Munandar (2008) stated that excessive and insufficient workload are stressors. The workload can be further distinguished as excessive/insufficient workload in quantitative, which arises from too many/fewer tasks given to the worker to complete within a certain period of time. The excessive/ insufficient workload in qualitative is if a worker cannot afford to do a task, or the task does not use the skills and/or workers' potential. In addition, excessive workload in both quantitative and qualitative can lead to over time-consuming work, which causes more stress.

The study was supported by Suryaningrum (2015) in PKU Muhammadiyah Hospital, Yogyakarta, which showed that workload has a positive effect on the stress among nurses in PKU Muhammadiyah Hospital with $(\beta)$ $0.165(\mathrm{p}<0.05 ; \mathrm{p}=0.033)$, and 2R2 workload on work stress among nurses in PKU Muhammadiyah Hospital is 0.026 .

Hermansyah and Mardiani (2016) also found a positive influence between intrinsic factors (workload, work routine and work environment) and work stress (path coefficient $=0.77$ ), which means that the more increase intrinsic factors (workload, work routine and the atmosphere of the work environment) experienced by the nurse, the more potential for them to have work stress in inpatient ward.

Likewise, the study of Zahro and Suhartoyo (2008) showed that workload is related to work stress among nurses in Central Surgery Installation $(\mathrm{p}=0.001)$. According to Caplan HI \& Soddack BJ (1992, in Zahro and Suhartoyo, 2008) workload is one source of stress. The workload can be caused by quantitative and qualitative overload. The quantitative overload, for example, the nurse do patient observation, check the preparation of the equipment, and others. While the qualitative overload, for example, the knowledge and skills possessed by nurses which cannot support the difficulty of work and high responsibility.

\section{Conclusion}

a. Of the 10 selected research articles, the smallest OR-value was 0.5 and the highest OR-value 
was 28.5. There were two studies that have OR values of $<2$, namely Pramudya (2008) with $\mathrm{OR}=1.56$ (95\% CI: 0.5-5.2), and Harahap (2016) with OR $=0.50$ (95\% CI: 0.1-3.5), while eight other studies showed OR values of $\geq 2$ which indicate that workload is one of the risk factors for the work stress among nurses in hospitals.

b. There was a significant correlation between workload and work stress among nurses in Indonesian hospitals as indicated by the combined $\mathrm{p}$-value $=0,000$ and combined $\mathrm{OR}=3.3$ (95\% CI: 2.3-4.7).

It is suggested to hospitals in Indonesia to: calculating and regulating the workload of nurses in each inpatient ward in order to reduce excessive burden on nurses by distributing or adding more nurses in heavierworkload wards, transferring nurses from the heavier-workload wards into less-workload wards so that it can reduce the work stress for nurses in heavier-workload wards, and assigning new nurses that previously work in less-heavy-workload ward to prevent work stress and gradually placed them in heavier-workload wards.

\section{References}

Anggreny, D.E., (2013). Analisis Faktor Yang berhubungan dengan Stres Kerja Pada Perawat di Rumah Sakit Islam Sti Khadijah Palembang. Jurnal Kesehatan Bina Husada Volume 10, N0. 3 November 2014. Hal. 385-389.

Anwar, R., (2005). Meta Analisis. Bandung. Fakultas Kedokteran Unpad.

Cicarelli, Saundra K, \& Meyer (2005). Psychology. New Jersey : Pearson Education Inc.

Coon, D. (2001). Psychology : Gateways to Mind and Behaviour (9th ed). USA : Thomson Learning

Dahlan, S., (2012). Seri 12 Pengantar Meta-Analisis : disertai aplikasi meta-analisis dengan menggunakan program excel. Sumedang : Alqaprint.

Dwijayanti, W. (2010). Stres kerja perawat pelaksana di ruang rawat inap RS Krakatau Medika tahun 2010. Skripsi. Tidak Dipublikasikan. Jakarta : FKM UI.

Ellis, N (2001). Work and Health : Management in Australia and New Zaeland. South Melbourn : Oxford University Pres

Ernawati, J. (2005). Hubungan stres kerja dan koping pada kepuasan kerja perawat di tiga Rumah Sakit Pemda DKI Jakarta. Tesis. Lontar. Ui.ac.id

Febriandini, E.A., Ma'rufi, I.A., Hartanti, R.I., (2015). Analisis Faktor Individu, Faktor Organisasi dan Kelelahan Kerja Terhadap Stres Kerja Pada Perawat (Studi di Ruang Rawat Inap Kelas III RSU dr. H. Koesnadi Kabupaten Bondowoso). E-Jurnal Pustaka Kesehatan, Vol. 4. No. 1 Januari 2016. Hal 176-180

Gibson. (2000). Organisasi, Perilaku; Struktur dan Proses. Alih bahasa: Agus Dharma. Jakarta: Penerbit Erlangga.

Gillies, D. A. (1996). Manajemen Keperawatan : Suatu pendekatan sistem, Philadelphia : W.B. Saunders Company.Swansburg RC. 1999. Pengantar Manajemen dan Kepemimpinan untuk perawat. Boston : John and Bartleet Publishing inc.

Greenberg, J. S. (2004). Comprehensive Sress Man-agement (8th Ed.). New York: Mc Graw Hill Companies.

Harahap, D.A., (2016). Faktor-faktor yang berhub-ungan dengan terjadinya Stres Kerja Pada Perawat ICU di Rumah Sakit Umum Daerah (RSUD) Rantauprapat. Skripsi-Universitas Sumatera Utara.

Haryanti, Aini. F., Purwaningsih, P. (2013). Hub-ungan Antara Beban Kerja Dengan Stres Kerja Perawat di Instalasi Gawat Darurat RSUD Kabupaten Semarang. Jurnal Managemen Keperawatan . Volume 1, No. 1, Mei 2013; 48-56.

Hasibuan, \& Melayu, S.P. (2002). Organisasi dan Motivasi. Cetakan Pertama. Jakarta : Bumi Aksara.

Hawari, D.(2001). Manajemen Stres Cemas dan Depresi. Jakarta : FKUI.

Hermansyah dan Mardiani (2016), Model Prediksi Pencegahan Stres Kerja Perawat Di Ruang Rawat Inap Rumah Sakit. Risbinakes. Poltekkes Kemenkes Bengkulu.

Higgins, J., et al. (2003). Cochrane Handbook for Systematic Review of Intervention. England : Wilet-Blackwell Publication.

Jusnimar (2012). Gambaran tingkat stres kerja perawat Intensive Care Unit (ICU) di Rumah Sakit Kanker Dharmais. Tesis. FIK-UI

Kozier, B., Erb, G., Berman, A., \& Snyder, S. (2010). Buku Ajar Fundamental Keperawatan. Jakarta : EGC

Kuruvilla, J. (2007). Essentials of critical care nursing. New Delhi : Jaypee

Marquis, B.L. 2000. Leadership role and management functions in nursing : theory and application. Third. Philadelphia : Lippincott.

Munandar, A. S. (2008). Psikologi Industri dan Organisasi. Jakarta: UI-Press.

Muthmainah, I. (2012). Faktor-Faktor Penyebab Stres Kerja di Ruangan Icu Pelayanan Jantung Terpadu dr. Cipto Mangunkusumo Jakarta. Skripsi, FIK-UI.

National Safety Council. (2004). Manajemen Stres. Jakarta : EGC

NIOSH. (2008). Exposure to Stress Occupational Hazards in Hospital. NIOSH. 
Pramudya, F.W. (2008). Faktor Yang Berhubungan Dengan Stres Kerja (Studi Kasus Pada Perawat Di RSKO Tahun 2008). Tesis. FKM-UI.

Prihatini, L. D. (2007). Analisis hubungan beben kerja dengan stres kerja perawat di setiap ruang rawat inap RSUD Sidikalang. Tesis. Fakultas Ilmu Keperawatan Universitas Sumatra Utara

Potter, P. A. \& Perry, A.G. (2005). Buku Ajar Funda-mental Keperawatan (Vol. 1). (Y. Asih, M. Sumarwati, D. Efriyani, \& dkk., Penerjemah). Jakarta: EGC.

Putra, B.S. (2013). Analisis Faktor-faktor Penyebab Stres Kerja Pada Perawat pelaksana Rumah Sakot Tugu Ibu Cimanggis Tahun 2013. Skripsi. FKM-UI

Rahmaniaty (2010). Analisis faktor-faktor yang berhubungan dengan stres kerja karyawan di bidang rekam medic RS kanker "Dharmais" tahun 2010. Skrip. Tidak Dipublikasikan, Jakarta : Fakultas Ilmu Keperawatan Universitas Indonesia.

Ratnaningrum, C., (2012). Tingkat Stres Perawat di Ruang Psikiatri Intensif Rumah Sakit Dr. H. Marzoeki Mahdi Bogor. Skripsi. FIK-UI.

Rini, J.F., (2002). "Wanita Bekerja”. http:/www.epsikologi.com/epsi/search.asp. Diakses pada tanggal 23 Januari 2017.

Robbins, S. P. (2004). Teori organisasi, struktur, desain, dan aplikasi. (Alih Bahasa: Tim Indeks). New Jersey: Prentice Hall.

Rosnawati, M. R., et al. (2010). The Bahasa melayu Version of The Nursing Stress Scale Among Nurses: A Reliability Study in Malaysia. Asia-Pasific Journal of Public Health , 2(4), 501-504.

Saragih, H. (2008). Pengaruh karakteristik Organ-isasional dan Individual terhadap Stres Kerja perawat di Ruang Rawat Inap Rumah Sakit Umum Daerah Porsea. Tesis. Sekolah Pasca Sarjana USU.

Sari, I.S., (2013). Faktor-faktor yang Berhubungan Dengan Stres Kerja Pada Perawat Rumah Sakit Jiwa Dr. Soeharto Heerdjan. Skripsi-Universitas Indonesia

Santroc, J. W (2000). Psychology. Toronto : Mc. Graw Hill Companies

Septian, Y.K., Ernawati, D. (2014). Faktor-faktor yang berhubungan dengan stress kerja pada Perawat di RumahSakit Jiwa Daerah Dr. Amini Dondoutomo Semarang 2014. Fakultas Kesehatan Universitas Dian Nuswantoro Semarang.

Siagian, S.P. (2001). Manajemen Sumber Daya Manusia. Jakarta : Bumi Aksara

Simanjorang, A. (2008). Pengaruh karakteristik organisasi terhadap stres kerja perawat di RSU dr. Pirngadi medan. Tesis. Fakultas Ilmu Keperawatan Universitas Sumatra Utara.

Soewondo, S. (2010). Manajemen Stres dengan Relaksasi Progresif. Depok : Tidak Diterbitkan

Spears, A. (2008). Work Related Stres. Victoria: Health and Safety Executive Inc

Suerni, T. (2012). Analisis factor yang Berhubungan dengan Tingkat Stres Perawat ICU di RSU di Jawa Tengah. Tesis. FIK-UI

Sugiyanto, (2004). Meta-Analysis. Yogyakarta. Fakultas psikologi UGM.

Suryaningrum, T., (2015). Pengaruh Beban Kerja Dan Dukungan Sosial Terhadap Stres Kerja Pada Perawat RS PKU Muhammadiyah Yogyakarta. Skripsi-Universitas Negeri Yogyakarta.

Sutrisna, B., Purwaningsih, E., dan Sunawang. (2009). Meta Analisis : Pengertian dan Prosedur untuk Bidang Kesehatan dengan Piranti Linak program STATA. Jakarta : Dian Rakyat.

Swansburg, R.C. (2000). Pengantar kepemimpinan dan manajemen keperawatan : Untuk peratan klinis, Jakarta : EGC.

Wagiu, C.F., Kolibu, F.K., Asrifuddin, A. (2017). Hubungan Antara Beban Kerja Dengan Stres Kerja Pada Perawat Di Ruang Rawat Inap Ru-mah Sakit Hermana Lembean. Fakultas Kesehatan Masyarakat Universitas Sam Ratu-langi

Waluyo, M. (2009). Psikolog Teknik Industri (Ed.1). Yogyakarta: Graha Ilmu.

Zahro dan Suhartoyo (2008). Beban Kerja Dan Lingkungan Kerja Dengan Stres Pada Perawat Instalasi Bedah Sentral. Journals of Ners Community Vol 4 No 1 Juni 2013. Hal 21-28. 